\title{
УДК 624.159.4
}

\author{
А. I. ЮХИМЕНКО ${ }^{*}$, Р. В. САМЧЕНКО ${ }^{2}$ \\ ${ }^{*}$ Кафедра промислового та цивільного будівництва, Запорізький національний університет, пр. Соборний, 226, м. Запо- \\ ріжжя, 69006, тел. +38 (095) 44713 65, ел. пошта winner.wcar@gmail.com, ORCID 0000-0003-4231-9602 \\ ${ }^{2}$ Кафедра промислового та цивільного будівництва, Запорізький національний університет, пр. Соборний, 226, м. Запо- \\ ріжжя, 69006, тел. +38 (050) 45481 65, ел. пошта sektor3@ukr.net, ORCID 0000-0003-1013-0047
}

\section{ЗАСАДИ МЕТОДУ ВІДНОВЛЕННЯ ДЕФОРМОВАНОГО СТАНУ БУДІВЕЛЬНИХ ОБ’СКТІВ}

Мета. Розробити засади узагальнюючого методу усунення деформованого стану будівель і споруд шляхом регулювання жорсткості основи фундаментів горизонтальними свердловинами змінних параметрів. Методика. Враховуючи, що в більшості випадків деформацій будівельних об’єктів виникають через нерівномірні осідання фундаментів із-за нерівномірних деформацій основ, при ліквідації деформацій доцільно йти шляхом нівелювання осідань фундаментів одним із технологічних прийомів - нерівномірним щілиноподібним вимиванням грунту основи із-під фундаменту стисненим струменем, нерівномірним ущільненням грунтів вібрацією та ін. Нами запропоновано бурінням горизонтальних свердловин змінних параметрів в шарі основи безпосередньо під фундаментом. Результати. На базі вказаної гіпотези запропонований на рівні винаходу спосіб вирівнювання нахилених будівель, споруд. Для його реалізації розроблений технологічний регламент, який полягає у геодезичних вимірюваннях кута нахилу об'єкту, горизонтального зміщення верху від вертикалі, визначення величини необхідного опускання менш осілої частини фундаменту бурінням горизонтальних свердловин. По розробленій методиці визначають параметри горизонтальних свердловин, по яким перфорують шар грунту під фундаментом. Наукова новизна. Обгрунтована можливість усунення деформованого стану будівель, споруд управлінням жорсткості основ фундаментів перфоруванням шару грунтів горизонтальними свердловинами змінних параметрів, при яких відбудовуються дзеркальні зворотні осідання фундаментів i, відповідно, будівля повертається в проектне положення. Практична значимість. Розроблений метод відновлення деформованого стану уніфікований. Метод застосовується для ліквідації деформацій об’єктів різних конструктивних форм: призматичних, круглих, баштових висотних, у т.ч. точкових (димових труб, силосних споруд). Ліквідація деформованого стану відбувається без відселення людей, без зупинки діяльності.

Ключові слова: деформації будівель; відновлення; осідання фундаменту; горизонтальні свердловини; перфорація

\section{Вступ}

Економіка багатьох країн світу страждає від наявності деформованих та аварійних будівельних об'єктів. При цьому деформації будівель, споруд відбуваються у різних формах - крени вигини, прогини, кручення та їх похідні - тріщиноутворення, зсуви із опорних поверхонь та ін. Причини виникнення деформованого стану різноманітні. Але найбільше вони виникають в регіонах із структурно-нестійкими грунтами просадочними, набухаючими, мерзлими та ін.

На просадочних територіях України, які займають біля $70 \%$ площі країни, внаслідок руйнування структури грунтів від замочування та навантаження від ваги об’єктів і власної ваги грунтів відбуваються суттєві деформації значної кількості будівель та споруд різної форми пошкоджень (Яковлєв, \& Винников, 1992). Найбільш небезпечний вид деформацій є крени, особливо, коли суміжні будинки або їх блок-секції нахиляються назустріч один одному, де можуть виникати їх зіткнення із замиканням деформаційних швів. В разі неприйняття своєчасних запобіжних заходів виникають аварійні ситуації (рис. 1).

Значна кількість деформованих об'єктів існує також на кориснодобуваючих територіях, де через складні процеси деформування товщі грунтів внаслідок виїмки корисних копалин, практично неможливо запобігати впливу геотехнічних факторів на об'єкти (Розенваcep, 2009). 
МОСТИ ТА ТУНЕЛІ: ТЕОРІЯ, ДОСЛІДЖЕННЯ, ПРАКТИКА

Не менш небезпечними є крени висотних баштових споруд призматичної форми, та особливо точкових, наприклад димових труб (Baраница, 2001).

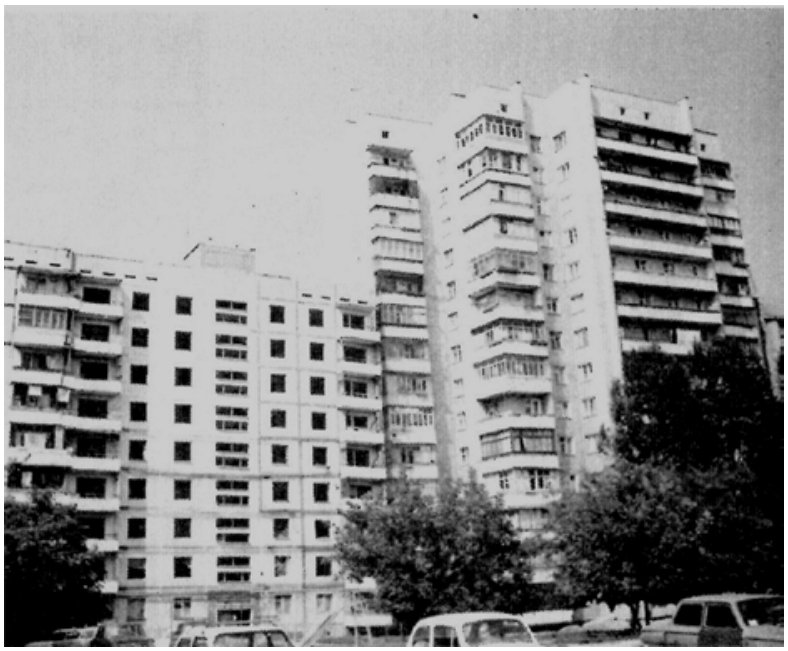

Рис. 1. Аварійний будинок № 6 по вул. Воронезькій у м. Запоріжжя

Таким чином, по різним причинам виникають серйозні деформації будівель, споруд, де при перших проявах їх виникнення необхідно терміново виясняти причини та негайно їх усувати. В противному випадку при нехтуванні даною тезою деформацій можуть стрімко розвиватися аж до аварійних ситуацій, про що сказано в багатьох джерелах інформації, але все-таки часто зустрічаються тяжкі наслідки (Емельянов, 1965; Ассоциация строительных вузов, 1995; Леденев, \& Скрылев, 2002).

В зв'язку із значною кількістю деформованих об'єктів, які збільшуються у часі, вчені та спеціалісти розробляють та застосовують різноманітні засоби по ліквідації деформованих станів або ж зменшенню їх впливу на ступінь пошкодження будівель, споруд. Цьому сприяють методи та технології укріплення грунтів та зміцнення основ. В останні роки широко застосовують метод підсилення основ бурозмішувальними технологіями, які базуються на змішуванні грунту із укріплюючими розчинами, частіше із цементним (Lambert, Rocher-Lacoste, \& Le Kouby, 2012; JianguoFan, 2015; Петренко, Тютькін, Крисан, В. І., \& Крисан, В. В., 2019). Більшість цих технологій направлені на утворення укріплюючих грунтоцементних армуючих елементів (ГЦЕ) у вертикальному напрямку (Зоценко, Бовкун, \& Маля- ренко, 2006). Але досить часто виникає необхідність укріплення грунтів у горизонтальному напрямку, наприклад для підсилення основ існуючих деформованих об'єктів.

Нами розроблений спосіб горизонтального укріплення грунтів основ армуванням горизонтальними ГЦЕ (Шокарев, Степура, I. В., \& Степура, C. I., 2015), сутність та технологія яких показані в (Юхименко, 2016). Наведені способи та технології сприяють зменшенню кількості деформованих будівель, споруд, але вони не усувають вже виниклих деформацій будівель.

\section{Мета}

Надати основи розробленого узагальнюючого методу усунення деформованого стану будівель, споруд.

\section{Методика}

Аналіз розглянутих джерел інформації показує, що більшість випадків деформування будівель, споруд відбувається через нерівномірні осідання фундаментів із-за нерівномірних деформацій основ. Тому є сенс розглянути можливість ліквідації деформацій будівель, споруд, або хоч зменшення їх впливу на деформований стан шляхом нівелювання нерівномірності осідань фундаментів. Вирівнювання деформацій основи i тим самим здійснення нівелювання осідань фундаментів можливо виконати бурінням горизонтальних свердловин перемінних параметрів в шарі основи під фундаментом, що адекватно зміні жорсткості основи. Жорсткість основи є мірило деформаційної характеристики основи, що вказує на іï здатність чинити опір переміщенню, або, навпаки, оцінювати умови можливості переміщення при певних обставинах (Клепиков, Трегуб, \& Матвеев, 1987). Під тиском будівлі та додаткового технологічного впливу зволоженням грунтів у ціликах та зводах між свердловинами перфорований шар основи, досягаючи межі міцності руйнується та піддається деформації стиску у відповідності до параметрів горизонтальних свердловин, методика розрахунків яких показана в (Самченко, 2013).

\section{Результати}

На основі даної гіпотези нами запропонований спосіб вирівнювання нахилених будівель (патент України №65455 А) (Степура, I. В.,

(c) А. І. Юхименко, Р. В. Самченко, 2020 
МОСТИ ТА ТУНЕЛІ: ТЕОРІЯ, ДОСЛІДЖЕННЯ, ПРАКТИКА

Шокарев, Павлов, \& Трегуб, 2003). Сутність даного способу викладена в роботі (Самченко, Юхименко, \& Степура, 2014) (рис. 2).

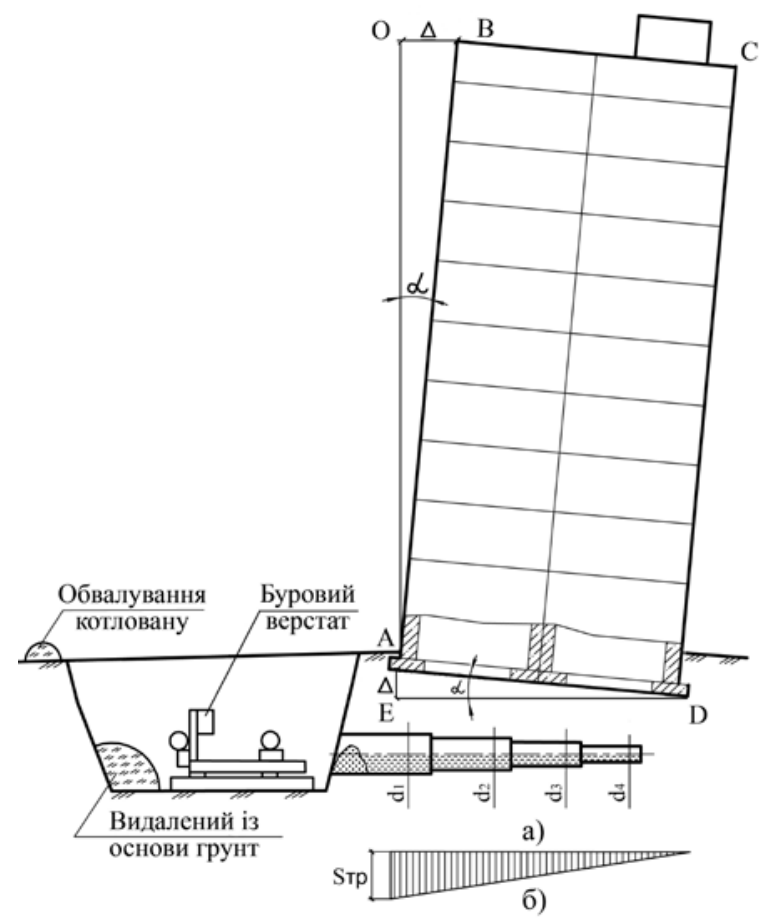

Рис. 2. Технологічна схема усунення поперечного крену:

а) параметри поперечного крену і свердловини змінних параметрів; б) епюра осідання фундаментів

Для реалізації способу відновлювання деформованого стану передбачений технологічний регламент, який полягає в наступному. Геодезичними методами - теодолітною зйомкою та геодезичним нівелюванням відзначають параметри нахилу будівлі - кут нахилу $\alpha$ і лінійне відхилення від вертикалі $\Delta$. По цім даним із подібності трикутників АОВ та АЕД визначають величину необхідного осідання ребра будівлі $\mathrm{AB}$ на величину $\mathrm{AE}$ призми грунту АДЕ, який заважає зайняти горизонтальне положення фундаменту, тобто лінія АД повинна співпасти із ЕД. Призму грунту АДЕ необхідно видалити із-під фундаменту бурінням горизонтальних свердловин, параметри яких визначають по методиці, викладеній в роботі (Самченко, 2013). По визначеним параметрам розробляють проект вирівнювання будівлі.

По вказаній методиці визначають параметри перфорування горизонтальними свердловинами шару основи будівель, споруд, фундаменти яких при осіданнях не викривляються, а осідають по лінійній закономірності.

Окрім ліквідації кренів, наведеною технологією можна усувати деформації вгинів, прогинів, будівель, фундаменти яких при нерівномірних осіданнях викривляються по одній із функцій параболи, гіперболи або іншим закономірностям (Павлов, \& Степура, 2006). Це будівлі кінцевої жорсткості, наприклад цегляні на збірних фундаментах із фундаментних подушок. Параметри перфорування горизонтальними свердловинами таких будівель визначають по емпіричним залежностям, отриманих шляхом обробки результатів експериментальних даних методом математичної статистики.

Усунення деформованого стану будівель, споруд методом управління жорсткістю основ фундаментів перевірено при його успішному впровадженні на 60 об'єктах різних конструктивних схем, в різних грунтових умовах зв'язних грунтів у вигляді штучних, ущільнених, водонасичених основ в різних регіонах України. В жодному випадку не посилились деформації будівель, споруд, не виникали надзвичайні ситуації при відновленні деформаційних станів. Роботи виконувались без відселення мешканців та без зупинки діяльності об'єктів. Вище наведене свідчить про ефективність та достовірність методу. Можна було б навести достатню кількість прикладів впровадження, але через вимоги обмеження самоцитування наведемо лише два приклади успішного вирівнювання нахилених димових труб висотою 40...1000 м (Самченко, 2014), або про ліквідацію деформованого стану будівель, споруд у водонасичених умовах (Юхименко, 2019).

\section{Наукова новизна та практична значимість}

Запропоновано метод відновлення деформованого стану будівельних об'єктів шляхом регулювання жорсткості основи фундаментів горизонтальними свердловинами змінних параметрів, новизна якого захищена патентом. Практична значимість обумовлена достатньою кількістю відновлених деформованих об’єктів різного призначення в різних регіонах України.

\section{Висновки}

1. На базі проведених досліджень обгрунтована можливість усунення деформованого стану будівель, споруд управлінням жорсткістю основ

(C) А. І. Юхименко, Р. В. Самченко, 2020 
фундаментів перфоруванням шару грунту горизонтальними свердловинами змінних параметрів.

2. Розроблений метод відновлення деформованих будівель, споруд уніфікований: по-перше, він придатний для ліквідації деформацій різних конструктивних схем; по-друге, даний метод дозволяє усувати різні види деформацій - крени, прогини, вигини, роз'єднання зіткнених будівель або їх блок-секцій при замиканні деформаційних швів.

3. Достовірність, простота та ефективність методу підтверджені при вдалому впроваджені на 60 об'єктах в різних регіонах України.

\section{СПИСОК ВИКОРИСТАНИХ ДЖЕРЕЛ}

JianguoFan. (2015). Soil-cement mixture properties and design considerations for reinforced excavations. Journal of Rock Mechanics and Geotechnical Engineering, 10, 791-797.

Lambert, S., Rocher-Lacoste, F. \& Le Kouby, A. (2012). Soil-cement columns, an alternative soil improvement method. Recent research, advances and execution aspects of ground improvementment works, $8,52-59$

Ассоциация строительных вузов. (1995). Аварии и катастрофы. Предупреждение и ликвидация последствий. Москва: Стройиздат.

Вараница, В. В. (2001). О кренах кирпичных дымовых труб. Вісник Донбаської державної академії будівниитва і архітектури, 5, 101-102.

Емельянов, А. А. (1965). Деформации и повреждения зданий из объёмных блоков. Анализ причин аварий и повреждений строительных конструкиий, 3, $84-108$.

Зоценко, М. Л., Бовкун, Ж. М., \& Маляренко, В. І (2006). Досвід і перспективи підсилення основ вертикальними грунтоцементними елементами у міському будівництві. Бетон и железобетон 6 Украине, 6, 24-28.

Клепиков, С. Н., Трегуб, А. С., \& Матвеев, И. В. (1987) Расчет зданий и сооружений на просадочных грунтах. Київ: Будівельник.

Леденев, В. В., \& Скрылев, В. И. (2002). Предупреждение аварий. Москва: Издательство Ассоциации строительных вузов.

Павлов, І. Д., \& Степура, I. В. (2006). Патент України
95510. Київ: Державне патентне відомство України.

Петренко, В. Д., Тютькін, О. Л., Крисан, В. І., \& Крисан, В. В. (2019). Відновлення міцносних та деформативних характеристик земляного полотна та його основи армуванням грунтоцементними елементами. Мости та тунелі: теорія, дослідження, практика, 16, 65-74.

Розенвасер, Г. Р. (2009). Развитие конструктивных мер защиты зданий и сооружений, строящихся в особо сложных геотехнических условиях. Современные проблемы строительства, 5, 63-72.

Самченко, Р. В., Юхименко, А. І., \& Степура, І. В. (2014). Про геотехнології відновлення деформованих будівель та забезпечення їх подальшої нормальної експлуатації. Збірник наукових праць Украӥнської державної академії залізничного транспорту, 148, 70-76.

Самченко, Р. В. (2014). Особливості технології усунення кренів димових труб регулюванням жорсткістю основ. Збірник наукових пращь Української державної академії залізничного транспорту, 148, 76-82.

Самченко, Р. В. (2013). Методика розрахунку параметрів вирівнювання нахилених будівель. Збірник наукових прачь (галузеве мачинобудування, будівництво), 3(38), 321-327.

Степура, I. В., Шокарев, В. С., Павлов, А. В. , \& Трегуб, А. С. (2003). Патент України 65455А. Київ: Державне патентне відомство України.

Шокарев, В. С., Степура, I. В., \& Степура, С. I. (2015). Патент України 101409. Київ: Державне патентне відомство України.

Юхименко, А. I. (2016). Дослідження процесів утворення горизонтальних армоелементів для укріплення грунтів основ споруд за бурозмішувальною технологією. Мости $m a$ тунелі: теорія, дослідження, практика, 10, 98-106.

Юхименко, А. І. (2019). Ліквідація деформованого стану будівель, споруд у водонасичених умовах. Вісник одеської державної академії будівниитва та архітектури, 75, 151-157.

Яковлєв, А. В., \& Винников, Ю. Л. (1992). Особливості проектування, будівництва, експлуатації будівель і споруд на лесовому трунті та зсувонебезпечній території Украӥни. Київ: НMК ВО.

\section{А. И. ЮХИМЕНКО ${ }^{1 *}$, Р. В. САМЧЕНКО ${ }^{2}$ \\ 1* Кафедра промышленного и гражданского строительства, Запорожский национальный университет, пр. Соборный, 226, г. Запорожье, 69006, тел. +38 (095) 44713 65, эл. почта winner.wcar@gmail.com, ORCID 0000-0003-4231-9602 \\ ${ }^{2}$ Кафедра промышленного и гражданского строительства, Запорожский национальный университет, пр. Соборный, 226, г. Запорожье, 69006, тел. +38 (050) 45481 65, эл. почта sektor3@ukr,net, ORCID 0000-0003-1013-0047}

(C) А. І. Юхименко, Р. В. Самченко, 2020 


\title{
ОСНОВЫ МЕТОДА ВОССТАНОВЛЕНИЯ ДЕФОРМИРОВАННОГО СОСТОЯНИЯ СТРОИТЕЛЬНЫХ ОБЬЕКТОВ
}

Цель Разработать основы обобщающего метода устранения деформированного состояния зданий и сооружений путем регулирования жесткости основания фундаментов горизонтальными скважинами переменных параметров. Методика. Учитывая, что большинство случаев деформаций строительных объектов происходят вследствие неравномерных осадок фундаментов из-за неравномерных деформаций оснований, при ликвидации деформаций целесообразно идти по пути нивелирования осадок фундаментов одним из технологических приемов - неравномерным щелеобразным вымыванием грунта основания из-под фундамента сжатой струей, неравномерным уплотнением грунтов вибрацией и др. Нами предложено бурение горизонтальных скважин переменных параметров в слое основания непосредственно под фундаментом. Результаты. На базе указанной гипотезы предложен на уровне изобретения способ выравнивания наклоненных зданий, сооружений. Для его реализации разработан технологический регламент, который заключается в геодезических измерениях угла наклона объекта, горизонтального смещения верха от вертикали, определение величины необходимого опускания менее осевшей части фундамента бурением горизонтальных скважин. По разработанной методике определяют параметры горизонтальных скважин, по которым перфорируют слой грунта под фундаментом. Научная новизна. Обоснована возможность устранения деформированного состояния зданий, сооружений управлением жесткости оснований фундаментов перфорированием слоя грунта горизонтальными скважинами переменных параметров, при которых восстанавливаются зеркальные обратные осадки фундаментов и, соответственно, здание возвращается в проектное положение. Практическая значимость. Разработанный метод восстановления деформированного состояния унифицирован. Метод применяется для ликвидации деформаций объектов различных конструктивных форм: призматических, круглых, башенных высотных, в т.ч. точечных (дымовых труб, силосных сооружений). Ликвидация деформированного состояния происходит без отселения людей, без остановки деятельности.

Ключевые слова: деформации зданий; восстановление; осадки фундамента; горизонтальные скважины; перфорация

\author{
A. I. YUKHYMENKO ${ }^{1 *}$, R. V. SAMCHENKO ${ }^{2}$ \\ ${ }^{1 *}$ Department of Industrial and Civil Engineering, Zaporozhye National University, 226 Soborny Ave., Zaporozhye, 69006, \\ tel. +38 (095) 44713 65, e-mail winner.wcar@gmail.com, ORCID 0000-0003-4231-9602 \\ ${ }^{2}$ Department of Industrial and Civil Engineering, Zaporozhye National University, 226 Soborny Ave., Zaporozhye, 69006, \\ tel. +38 (050) 45481 65, email mail sektor3@ukr, net, ORCID 0000-0003-1013-0047
}

\section{BASICS OF THE METHOD FOR RESTORING THE DEFORMED STATE OF CONSTRUCTION OBJECTS}

Purpose. To develop bases of the generalizing method of elimination of a deformed condition of buildings and constructions by regulation of rigidity of the basis of the bases by horizontal wells of variable parameters. Methodology. Considering that most cases of deformations of construction objects receive deformations due to uneven settlement of foundations due to uneven deformations of the bases, when eliminating deformations, it is advisable to follow the path of leveling the settlement of foundations by one of the technological methods - uneven crevice-like leaching of the foundation soil from under the foundation by a compressed jet, uneven soil compaction by vibration, etc. We have proposed drilling horizontal wells with variable parameters in the base layer directly under the foundation. Results. On the basis of this hypothesis, a method for leveling inclined buildings and structures is proposed at the level of the invention. For its implementation, a technological regulation has been developed, which consists in geodetic measurements of the angle of inclination of the object, horizontal displacement of the top from the vertical, determining the value of the required lowering of the less settled part of the foundation by drilling horizontal wells. According to the developed technique, the parameters of horizontal wells are determined, through which the soil layer under the foundation is perforated. Originality. The possibility of eliminating the deformed state of buildings and structures by controlling the stiffness of the foundations by perforating the soil layer with horizontal wells of variable parameters is substantiated, at which the mirror reverse settlement of the foundations is restored and, accordingly, the building returns to the design position. Practical value. The developed method for restoring the 
deformed state is unified. The method is used to eliminate deformations of objects of various structural forms: prismatic, round, tower high-rise, incl. point (chimneys, silos). The elimination of the deformed state occurs without resettling people, without stopping activity.

Keywords: building deformations; restoration; foundation settlement; horizontal wells; perforation

\section{REFERENCES}

JianguoFan. (2015). Soil-cement mixture properties and design considerations for reinforced excavations. Journal of Rock Mechanics and Geotechnical Engineering, 10, 791-797. (in English)

Lambert, S., Rocher-Lacoste, F. \& Le Kouby, A. (2012). Soil-cement columns, an alternative soil improvement method. Recent research, advances and execution aspects of ground improvementment works, 8, 52-59. (in English) Assotsiatsiya stroitelnykh vuzov. (1995). Avarii i katastrofy. Preduprezhdenie i likvidatsiya posledstviy. Moskva: Stroyizdat. (in Russian)

Varanitsa, V. V. (2001). O krenakh kirpichnykh dymovykh trub. Visnyk Donbaskoi derzhavnoi akademii budivnytstva i arkhitektury, 5, 101-102. (in Russian)

Yemelyanov, A. A. (1965). Deformatsii i povrezhdeniya zdaniy iz obemnykh blokov. Analiz prichin avariy $i$ povrezhdeniy stroitelnykh konstruktsiy, 3, 84 - 108. (in Russian)

Zotsenko, M. L., Bovkun, Zh. M., \& Maliarenko, V. I. (2006). Dosvid i perspektyvy pidsylennia osnov vertykalnymy gruntotsementnymy elementamy u miskomu budivnytstvi. Beton i zhelezobeton v Ukraine, 6, 24-28. (in Ukrainian) Klepikov, S. N., Tregub, A. S., \& Matveev, I. V. (1987) Raschet zdaniy i sooruzheniy na prosadochnykh gruntakh. Kiev: Budivelnik. (in Russian)

Ledenev, V. V., \& Skrylev, V. I. (2002). Preduprezhdenie avariy. Moskva: Izdatelstvo Assotsiatsii stroitelnykh vuzov. (in Russian)

Pavlov, I. D., \& Stepura, I. V. (2006). Patent Ukrainy 95510. Kyiv: Derzhavne patentne vidomstvo Ukrainy. (in Ukrainian)

Petrenko, V. D., Tiutkin, O. L., Krysan, V. I., \& Krysan, V. V. (2019). Vidnovlennia mitsnosnykh ta deformatyvnykh kharakterystyk zemlianoho polotna ta yoho osnovy armuvanniam gruntotsementnymy elementamy. Mosty ta tuneli: teoriia, doslidzhennia, praktyka, 16, 65-74(in Ukrainian)

Rozenvaser, G. R. (2009). Razvitie konstruktivnykh mer zashchity zdaniy i sooruzheniy, stroyashchikhsya v osobo slozhnykh geotekhnicheskikh usloviyakh. Sovremennye problemy stroitelstva, 5, 63-72. (in Russian)

Samchenko, R. V., Yukhymenko, A. I., \& Stepura, I. V. (2014). Pro heotekhnolohii vidnovlennia deformovanykh budivel ta zabezpechennia yikh podalshoi normalnoi ekspluatatsii. Zbirnyk naukovykh prats Ukrainskoi derzhavnoi akademii zaliznychnoho transportu, 148, 70-76. (in Ukrainian)

Samchenko, R. V. (2014). Osoblyvosti tekhnolohii usunennia kreniv dymovykh trub rehuliuvanniam zhorstkistiu osnov. Zbirnyk naukovykh prats Ukrainskoi derzhavnoi akademii zaliznychnoho transportu, 148, 76-82. (in Ukrainian)

Samchenko, R. V. (2013). Metodyka rozrakhunku parametriv vyrivniuvannia nakhylenykh budivel. Zbirnyk naukovykh prats (haluzeve mashynobuduvannia, budivnytstvo), 3(38), 321-327. (in Ukrainian)

Stepura, I. V., Shokarev, V. S., Pavlov, A. V. , \& Trehub, A. S. (2003). Patent Ukrainy 65455A. Kyiv: Derzhavne patentne vidomstvo Ukrainy. (in Ukrainian)

Shokarev, V. S., Stepura, I. V., \& Stepura, S. I. (2015). Patent Ukrainy 101409. Kyiv: Derzhavne patentne vidomstvo Ukrainy. (in Ukrainian)

Yukhymenko, A. I. (2016). Doslidzhennia protsesiv utvorennia horyzontalnykh armoelementiv dlia ukriplennia gruntiv osnov sporud za burozmishuvalnoiu tekhnolohiieiu. Mosty ta tuneli: teoriia, doslidzhennia, praktyka, 10, 98-106. (in Ukrainian)

Yukhymenko, A. I. (2019). Likvidatsiia deformovanoho stanu budivel, sporud u vodonasychenykh umovakh. Visnyk odeskoi derzhavnoi akademii budivnytstva ta arkhitektury, 75, 151-157. (in Ukrainian)

Yakovliev, A. V., \& Vynnykov, Yu. L. (1992). Osoblyvosti proektuvannia, budivnytstva, ekspluatatsii budivel i sporud na lesovomu grunti ta zsuvonebezpechnii terytorii Ukrainy. Kyiv: NMK VO. (in Ukrainian)

Надійшла до редколегії 06.09.2020.

Прийнята до друку 09.10.2020.

(C) А. І. Юхименко, Р. В. Самченко, 2020 